\title{
IMPACT OF HIGH TECHNOLOGY EXPORT ON ECONOMIC GROWTH: AN ANALYSIS ON TURKEY
}

DOI: 10.17261/Pressacademia.2019.1123

JBEF-V.8-ISS.3-2019(3)-p.165-172

\section{Begum Erdil Sahin}

Istanbul Kultur University, Department of Economics, Istanbul, Turkey. b.sahin@iku.edu.tr, ORCID: 0000-0003-0452-1308

Date Received: June 6, 2019

Date Accepted: August 18, 2019

To cite this document

Erdil Sahin, B., (2019). Impact of high technology export on economic growth: an analysis on Turkey. Journal of Business, Economics and Finance (JBEF), V.8(3), p.165-172.

Permemant link to this document: http://doi.org/10.17261/Pressacademia.2019.1123

Copyright: Published by PressAcademia and limited licenced re-use rights only.

\begin{abstract}
Purpose- High-technology exports, with their high added value, are considered as one of the determinants of growth in recent years. The increasing competitiveness of developing countries in international markets depends on the country's capacity to produce and export high-tech products. Therefore, the export of high technology products is especially important for the economic growth and development of the countries. In this study, the effects of the causality analysis on the economic growth of high-technology exports in Turkey has been investigated.

Methodology- Granger Causality Analysis was used to determine the direction of the relationship and the results of the variance decomposition were evaluated. VAR model is primarily applied in the model in order to determine the short-term causality relationship between the variables while the analysis is performed with the Granger causality, impulse-response and variance decomposition methods.

Findings- After 1980, Turkey has transitioned from import substitution to export-oriented industrialization strategies and largely completed the liberalization process during 1990s. Important policies for industrialization have been implemented by improving the export structure within the scope of competitive advantages. When the impulse-response and variance decomposition results are evaluated together, the outcome is consistent with the Granger Causality Test results where high-technology export is effective on GDP.

Conclusion- In conclusion, it was found out that high technology exports affect economic growth. Therefore, Turkey has to put more emphasis to increase high technology shares in its exports and incentivize high technology production.
\end{abstract}

Keywords: Technology intense exports, economic growth, causality analysis, VAR analysis, Turkey JEL Codes: E60, 011, 047

\section{INTRODUCTION}

The ability to transform the knowledge into innovation and to use it in today's world determines the international competitive power of countries. Therefore, many countries are in an effort to open their national economies to foreign countries and to integrate it with the world economy. Within such scope, economic growth and development of countries and creating employment opportunities are not only associated with their abilities to innovate, but also it is closely associated with their potential to export these innovations. The countries need to develop, make production for increasing their competitive power, and market the said production abroad (Avcl et. Al., 2016: 50-51).

Since high-technology production means the production of high value-added products at the same time, particularly the developed countries have the leading positions worldwide in terms of exports including high-technology products. Therefore, production and export of the products including high-technology products are important factors in terms of financing the growth and development of countries, which have adopted export-oriented growth, through increasing their export revenues (Yıldız, 2017: 27). 
There are many factors that are effective on ensuring economic growth and its sustainability. Particularly, having high-technology sectors, manufacturing goods with high added value, and increasing exports have an important share amongst these factors. Specifically, high-technology efficiency is seen as the driving force behind economic development and growth for the countries implementing an export-oriented growth policy (Hobday et. al., 2001: 209). Therefore, increasing the share of high-technology products within the total exports takes part among the main objectives of countries in terms of international competition and economic growth.

When differences between the countries' income per capita and economic growth levels are examined, it is understood that the technological infrastructure, natural resources, manpower, economic and political stability are the important determinants. Developing countries transfer technology into their own countries in order to reach to the level of developed countries; allocate a higher share of resources to education; and try to foster research and development activities (Göçer, 2013: 216).

Turkey has gone into the effort of opening its economy to foreign countries, and to integrate with the world countries especially after 1980. In this regard, the policies based on import substitution were replaced by export-oriented policies, and important steps were taken towards financial liberalization in 1989. The relationship between high-technology export and economic growth in Turkey is analyzed for the period of 1989-2017 in this study. Granger causality test is utilized to analyze this relationship, and results of the impulse and response and variance decomposition are evaluated.

According to the decisions taken on January $24^{\text {th }}, 1980$ in Turkey, export-oriented development policy was commenced to be implemented, and the export activities started to increase with membership to the Customs Union in 1996. A significant change occurred in the structure of export, which consisted of labor-intensive products such as agriculture and textile products, in 1980s when durable household goods such as major home appliances and automotive parts replaced labor-intensive products in export. However, export of Turkey featuring high-technology products hasn't reached to the desired level despite such change. Since imported input is predominantly utilized in the production process for Turkey, an increase in the industries' production, which is performed through employment of high-technology, also increases the demand for imported input. At the same time, a significant portion of the added value to be obtained thereof goes abroad because the local industries, which may provide input to hightechnology industries in Turkey, are not sufficiently developed (Konak, 2018: 71-72).

Export shares of industries according to their technology levels is an important indicator demonstrating the technological production levels. Accordingly, industries are grouped as low-technology, medium low-technology, medium high-technology and high-technology. The shares of Turkey's export between the years 2003 and 2019, following Turkey's membership to the Customs Union, are given below according to levels of technology.

\section{Graph 1: Distribution of Imports of Turkey According to Technological Status (\%)}

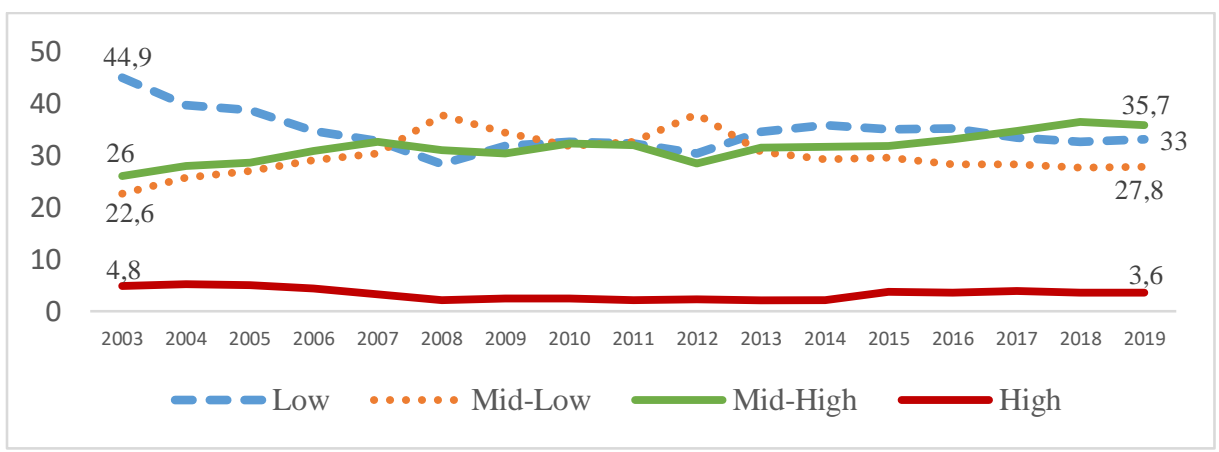

Source: TÜiK

Turkey's exports technological structure is undergoing a transformation according to the share of exports by technological level. In the beginning of 2000s, while almost half of its exports are produced with low technology, later this share has decreased over time, whereas the exports of products with low-medium and medium-high technologies have increased consistently. However, the exports of high-tech products remains at similar low levels.

According to first quarter data of 2019, Turkey's low technology share in total exports is 33\%, low-medium technology is $27.8 \%$, medium-high technology is $35.7 \%$ and high technology is $3.6 \%$. 
The main reasons for the low level of exports of Turkey can be associated with import high value-added products rather than produce locally, low level of shares allocated to research and development activities, lack of skilled labor, lack of direct foreign capital inflows and innovation policies. Developed countries have transformed their low and medium technology production capacities like textile, clothing, machinery, plastics, into advanced technology and high-value-added production like electronics, computers, software, pharmaceuticals, aircraft. Turkey has remained behind this technological development and competition (ilhan and Gelgeç, 2018: 35-54).

\section{LITERATURE REVIEW}

Capital movements between the countries have accelerated with the increase in international trade, and accordingly the pace of advancement in technology increased depending on this development. Within that context, the will to possession of hightechnology has become one of the primary goals of both developed and developing countries because countries may manufacture products with high added value by this means, and export these products alongside gaining competitive power in international markets. One of the most important targets of countries in today's world is exporting products with high added values and hightechnology (Saray and Hark, 2015: 348).

Furthermore, the studies which discuss the effects of export on economic growth, address various benefits such as increasing efficiency arising from exports; facilitation of capital goods imports through the revenues to be obtained from exports; utilization from scale economies depending on the increase in scales of relevant companies; and transfer of new information and methods into the country via the relations to be established with foreign markets through export operations (Gerni et. al., 2008: 5). The recently conducted studies particularly emphasize the importance of high-technology exports. Accordingly, empirical studies conducted with the objective of explaining the relationship between high-technology exports and economic growth are given place in this part.

Cuaresma and Wörz (2005) tested the hypothesis that exports in technology-intensive industries have a higher potential for positive externalities coupled with higher productivity levels using a data set, covering 45 industrialized and developing countries for time period 1981-1997. The estimation results, using a random effects model and employing an instrumental variables estimator, support the hypothesis of qualitative differences between high- and low-technology exports with respect to output growth.

In the study of Değer (2007), aimed to reveal the importance of the product composition of exports in the economic growth processes of the developing countries and concluded that technology-intensive product exports have positive effects on economic growth. The biggest and significant effect on economic growth is labor intensive manufacturing industry exports.

In the study of Falk (2009), new evidence on the impact of the change in the high-tech export share on economic growth in OECD countries was presented with a dynamic growth model on panel data for 22 OECD countries for 1980-2004, in which the data is measured as 5-year averages. It found out that both business R\&D intensity and the share of high-tech exports are significantly positively related to the GDP per working age population.

Lee in the paper dated 2011, empirically investigated the extent to which technological characteristics in exports affect the patterns of trade-led economic growth across countries. The findings are robust to the presence of various control variables as well as the consideration of parameter heterogeneity and in the endogeneity of export structures.

In the study of Kılavuz and Topcu Altay (2012), the effect of different classifications of export and import on economic growth in 22 developing countries in the 1998-2006 period was tested. The findings revealed that only high-technology manufacturing industry export, investment and low-tech manufacturing industry import have a positive and significant effect on growth.

Göçer (2013) examined effects of R\&D expenditures on high technology exports, information-communication technology exports, total exports and economic growth as well as the effects of high technology exports on the balance of foreign trade for 11 developing Asian countries by using data of 1996-2012 period. As a result of the analysis, it has been determined that an increase by $1 \%$ in R\&D expenditures raised the high technology export by $6.5 \%$, the information-communication technology exports by $0.6 \%$ and the economic growth by $0.43 \%$.

In their 2013 study, Aditya and Acharya investigated the export-growth relationship at disaggregate levels - disaggregation both at the country level and at the level of exports - focusing on the diversification and the composition of exports of countries. In a sample of 65 countries for the period 1965-2005 the dynamic panel estimation reveals that both diversification and composition of exports are important determinants of economic growth after controlling for the impacts of other variables like lagged income, investment, and infrastructure. 
Telatar, Değer and Doğanay (2016) investigated the effect of technology intensity product export on economic growth with time series analysis for Turkey. According to the findings obtained from co-integration testing results, low and medium technology intensive products have significant and positive effects on Turkey's economic growth. On the other hand, according to Granger causality results, there are unidirectional causal relationships from exports of medium and high technology intensive products to economic growth.

Yıldız (2017) investigated the effect of the high- technology export on the economic growth for BRICS countries and Turkey for the period 2005- 2014 is analyzed by using panel data techniques. The results of show that high- technology export is significantly positive effect on the economic growth for BRICS countries and Turkey.

Özkan and Yılmaz (2017) examined the share of R\&D expenditures in GDP, the share of high-technology exports in total exports and its relationship with GDP via data of 1996-2015 period for Turkey, and 12 member countries of the European Union. The results for the entire panel reveal that R\&D expenditures positively affect high-technology exports and GDP.

In the study of Kızılkaya, Sofuoğlu and Ay in 2017, they examined the effect of foreign direct investment and openness on high technology product export with panel data analysis method in 12 developing countries over the period of 2000-2012. According to analysis results, foreign direct investment and openness have a positive impact on high technology product export. Within the framework of empirical findings, we presented some policy recommendations for developing countries.

In the study of Konak (2018) analyzed World Bank data of 1992-2016 period for selected OECD member countries and Turkey's high technology export and its impact on economic development. According to the analysis result, Turkey's exports mainly are based on "low", "medium-low" and "medium-advanced" technology.

\section{DATA AND METHODOLOGY}

The relationship between high-technology exports and economic growth in Turkey for the period 1989-2017 is tested by using the Granger causality test in this study. The Augmented Dickey-Fuller (ADF) tests are preferred for examining the stationarity of series in the analysis. VAR model is primarily applied in the model in order to determine the short-term causality relationship between the variables while the analysis is performed with the Granger causality, impulse-response and variance decomposition methods. Gross Domestic Product (GDP) and high-technology export amount (HTE) variables are used as economic growth indicators in the analysis where annual series from the 1980-2016 period are employed. The data set employed in the analysis has been obtained from the World Bank.

\section{FINDINGS AND DISCUSSION}

\subsection{Stationarity Analysis}

Fake regression problem may be encountered when worked with the non-stationary time series in the econometric analysis studies. Therefore, the stationarity of variables should be checked before analyzing the relationship between variables. Otherwise, using the non-stationary series in analysis may lead to obtaining unreliable results including spurious relationships (Sevüktekin and Nargeleçekenler, 2007: 312). Therefore, Augmented Dickey-Fuller (ADF) unit root test, in other words stationarity analysis, was performed in this study. If the variables are not stationary at the level value in the stationarity analysis, differences of the series are taken and they are made stationary. If the test statistics are smaller than the determined critical value in the analysis, the series is accepted as stationary (Kaya and Öz, 2016: 644).

Table 1: ADF Unit Root Test Results

\begin{tabular}{|c|c|c|c|}
\hline Variables & & ADF-t Statistics with Constant Term & $\begin{array}{c}\text { ADF-t Statistics with Constant Term and } \\
\text { Trend }\end{array}$ \\
\hline HTE & 1 & $-2.845159[0.0654]$ & $-2.789584[0.2127]$ \\
\hline GDP & Level & $-5.720186[0.0001]^{*}$ & $-5.726882[0.0004]^{*}$ \\
\hline DHTE & $1^{\text {st }}$ Difference & $-4.098447[0.0039]^{*}$ & $-4.019207[0.0203]^{*}$ \\
\hline DGDP & & - & - \\
\hline
\end{tabular}


*In the model with constant term, MacKinnon critical values are $-3.69,-2.97$ and -2.62 for the significance levels of $1 \%, 5 \%$ and $10 \%$ respectively. In the model with constant term and trend, the values are $-4.33,-3.58$ and -3.22 respectively. The figures in between the square brackets correspond to probability values.

As may be seen in Table 1, since the absolute values of ADF-t statistics, which are obtained for the HTE variable at the level values, are smaller than the MacKinnon absolute values at significance levels of $1 \%, 5 \%$ and $10 \%$, they are non-stationary. When the first differences of this variable are taken, it is determined to be stationary. GDP variable is determined to be stationary at the level.

The assumption that errors are independent from each other and have constant variance in the ADF test causes problems when both autoregressive and moving-average elements are involved. Philips (1987) and Philips and Perron (1988) developed a unit root test with the assumption that there may be autocorrelation and heteroscedasticity between the error terms. Due to both the autocorrelation and heteroscedasticity problem as well as the objective to obtain healthier information on stationarity of these variables, Philips-Perron (PP) test is also utilized in this study in addition to the ADF test. The results of the PP tests are listed in the below table.

Table 2: PP Unit Root Test Results

\begin{tabular}{lccc}
\hline Variables & PP-t Statistics with Constant Term & PP-t Statistics with Constant Term and \\
Trend
\end{tabular}

*In the model with constant term, MacKinnon critical values are $-3.69,-2.97$ and -2.62 for the significance levels of $1 \%, 5 \%$ and $10 \%$ respectively. In the model with constant term and trend, the values are $-4.33,-3.58$ and -3.22 respectively. The figures in between the square brackets correspond to probability values.

When results of the stationarity test are considered in the Philips-Perron test method, it is seen that the GDP variable is stationary at the level while the HTE variable becomes stationary when its first difference is taken just as in the ADF test.

\subsection{Granger Causality Test}

Granger causality test is applied in order to determine direction of the relationship between the high-technology export and economic growth variables. Granger causality test is conducted with the help of below-given equations (Granger, 1969: 424-438).

$Y_{t}=\sum_{i=1}^{m} \alpha_{i} Y_{t-i}+\sum_{j=1}^{m} B_{j} X_{t-j}+u_{1 t}$

$X_{t}=\sum_{i=1}^{m} \lambda_{i} X_{t-i}+\sum_{j=1}^{m} \delta_{j} Y_{t-j}+u_{2 t}$

Here $m$ expresses the lag length and the error terms of $u_{1 t}$ and $u_{2 t}$ are assumed to be independent from each other (Granger, 1969: 431). In Granger causality can be both from $X$ to $Y$ and from $Y$ to $X$. The dependent variable is first added to the model with an appropriate lag count, and then the other variable is added to the model. The error sum of squares pertaining to these models are figured, and then the F statistics, which is developed by Wald, is calculated (Yılmaz, 2005: 70).

$F(m ; n-2 m)=\frac{\left(E S S_{r}-E S S_{u r}\right) / m}{\left(E S S_{u r}\right) / n-2 m}$

ESS: Error Sum of Squares, ur: Unlimited Model, r: Limited Model

If the calculated $F$ statistics is bigger than the table value in the $\alpha$ significance level and (m; $n-2 m)$ degree of freedom, null hypothesis is rejected. Rejection of this hypothesis shows that the coefficients in this model are significant. For instance, in case 
there is causality from the Xt variable to the Yt variable, the coefficients of variables included in the equation numbered (1) become statistically significant (Granger, 1969: 431).

The second step required for determination of lag count of the model to be established is creating the VAR model, and setting the appropriate lag count. The appropriate VAR model lag length is determined as 2 according to the LR, FPE, AIC and HQ criteria.

Table 3: Granger Causality Test Results

\begin{tabular}{lcl}
\hline Ho Hypothesis & X2 Statistics & Prob. Value \\
\hline HTE is not the cause of GDP. & 7.793882 & 0.0203 \\
GDP is not the cause of HTE. & 0.972283 & 0.6150 \\
\hline
\end{tabular}

According to the short-term Granger causality test results, the null hypothesis "HTE is not the cause of GDP" is rejected. Similarly, the null hypothesis "GDP is not the cause of HTE" is accepted. In line with these findings, it is accepted that there is a one-way causality relationship between high-technology export and economic growth in the short term.

\subsection{Variance Decomposition and Impulse-Response Analysis}

The dynamic relations between the variables are examined with the variance decomposition and impulse-response analysis in the VAR model. It is examined in variance decomposition what percent of the change in variance of a variable results from itself, and what percent thereof results from other variables. Variance decomposition may be also used as an auxiliary assessment about whether the variables are internal or external. Accordingly, if almost one hundred percent of a change in a variable's variance is explained by its own value, this variance is characterized as an external variable. Impulse-Response Analysis is a method employed for determining the effect of one-unit standard deviation shock, which is delivered from one variable to another, on the dependent variable, and the length of this effect (Tarı, 2006: 452-453).

This part features variance decomposition and impulse-response analysis for the purpose of determining the dynamic relations between variables within the framework of causality test results.

Table 4: Variance Decomposition Results

\begin{tabular}{llll}
\hline GDP & & & \\
\hline Period & Standard Error & GDP & HTE \\
1 & 4.360069 & 100.0000 & 0.000000 \\
2 & 4.379315 & 99.75651 & 0.243490 \\
3 & 4.978535 & 77.73090 & 22.26910 \\
4 & 5.016217 & 76.77783 & 23.22217 \\
5 & 5.069174 & 75.44024 & 24.55976 \\
6 & 5.101110 & 74.49860 & 25.50140 \\
7 & 5.102170 & 74.50914 & 25.49086 \\
8 & 5.108787 & 74.32718 & 25.67282 \\
9 & 5.110384 & 74.28205 & 25.71795 \\
10 & 5.110721 & 74.27642 & 25.72358 \\
HTE & & & \\
Period & Standard Error & GDP & HTE \\
1 & 0.666120 & 8.234795 & 91.76521 \\
2 & 0.692456 & 8.626787 & 91.37321 \\
3 & 0.707590 & 9.100023 & 90.89998 \\
4 & 0.723876 & 8.707398 & 91.29260 \\
5 & 0.724524 & 8.792722 & 91.20728 \\
6 & 0.726997 & 8.780730 & 91.21927 \\
7 & 0.727980 & 8.758007 & 91.24199 \\
8 & 0.728054 & 8.768740 & 91.23126
\end{tabular}


When we examine the exposition of high-technology export on GDP, it is seen that the changes occurring in GDP mostly results from itself, but this weight starts to decrease after the second period. While the exposition of share of high-technology export is approximately 22 in the third period, it rises to 25.72 in the tenth period. When the variance decomposition results of hightechnology export are evaluated, it is seen that the rate of GDP explaining the change in high-technology export is around 8.7 through several periods, and that it doesn't demonstrate any major changes.

\section{Graph 2: Impulse - Response Results}

\section{Response of GDP to HIGH-TECH}

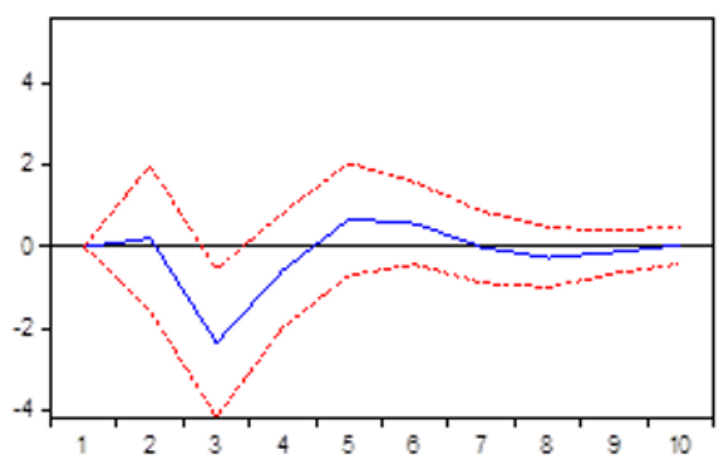

Response of HIGH-TECH to GDP

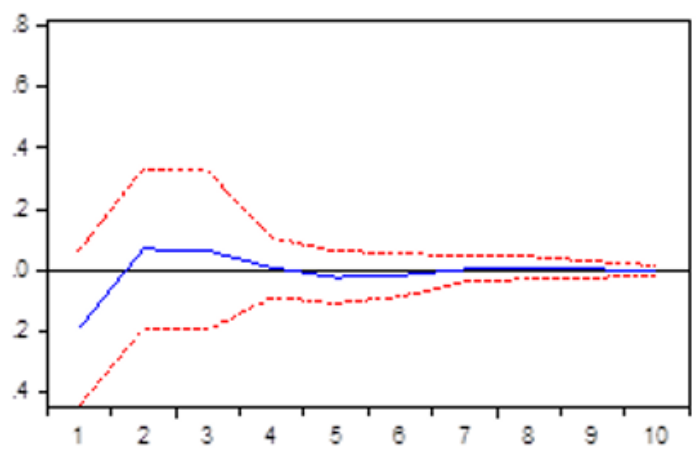

It is seen in Graph 2 that the effect of a shock occurring in high-technology export on GDP starts to response positively after the second month, then the degree of response increases following which the effect diminishes until it gets closer to zero. However, the effect of a one-unit shock occurring in GDP first reacts negatively, but a positive increase is experienced after the fifth month, and eventually the effect is observed to diminish.

When the impulse-response and variance decomposition results are evaluated together, the outcome is consistent with the Granger Causality Test results where high-technology export is effective on GDP.

\section{CONCLUSION}

Competitiveness in international markets is increasingly dependent on the capacity to produce and export technology. The development of trade relations between countries increases the economic growth by providing consumers with higher quality and cheaper consumption, while increasing the country's competitiveness. Countries that want to get more share of this competitive environment need to allocate more shares to high technology product exports.

Turkey, after the 1980, has started to implement export oriented and externally open industrialization policies in order to increase the share in the global competition. However, although there has been a transformation and change in the industry, it is observed that in terms of production and added value, low and medium-low technology products still have the highest shares. The share of high-technology products in exports is very low. The fact that domestic demand for high and medium high technology products is imported from abroad, this leads to the country imports being higher than exports.

In this study, the impact of economic growth of high-technology exports in Turkey was examined by Granger causality analysis, variance decomposition and impulse-response analysis. The results reveal the importance of high technology exports in terms of ensuring high and sustainable economic growth. As a result of the causality analysis, it has been determined that there is a causal relationship between high technology product exports and economic growth. In addition, the results of variance decomposition and impulse-response analyzes also support this relationship. Therefore, Turkey has to put more emphasis to increase high technology shares in its exports and incentivize high technology production. 


\section{REFERENCES}

Aditya, A. and Acharya, R. (2013). Export Diversification, Composition and Economic Growth: Evidence From Cross-Country Analysis. The Journal of International Trade \& Economic Development An International and Comparative Review. 22(7): 959-992.

Avcı, M., Uysal, S. and Taşçı, R. (2016). Türk İmalat Sanayinin Teknolojik Yapısı Üzerine Bir Değerlendirme. Journal of Social Sciences and Humanities Researches. 17(36): 49-66.

Cuaresma, J.C. and Wörz, J. (2005). On Export Composition and Growth. Weltwirtschaftliches Archiv. 141(1): 33-49.

Değer, M. K. (2007). İhracatın Kompozisyonu ve Ekonomik Büyüme: Orta Gelirli Ülkeler Üzerine Panel Veri Analizleri (1982-2004). Ankara, İmaj Yayınevi.

Falk, M. (2009). High-Tech Exports and Economic Growth in Industrialized Countries. Applied Economics Letters. 16(10): 1025-1028.

Gerni, C., Değer, M. K. and Emsen, Ö. S. (2008). İthalata Dayalı İhracat ve Ekonomik Büyüme: 1980-2006 Türkiye Deneyimi. 2. Ulusal Ekonomi Konferansı, Dokuz Eylül Üniversitesi, İzmir, 1-21.

Göçer, I. (2013). Ar-Ge Harcamalarının Yüksek Teknolojili Ürün İhracatı, Dış Ticaret Dengesi ve Ekonomik Büyüme Üzerindeki Etkileri. Maliye Dergisi. 165: 215-240.

Granger, C.W.J. (1969). Investigating Causal Relations By Econometric Models and Cross-Spectral Methods. Econometrica. 37(3): 424-438.

Hobday, M., Cawson, A. and Kim, S. R. (2001). Governance of Technology in The Electronics Industries of East and South-East Asia. Technovation. 21(4): 209-226.

Illhan, B. and Gelgeç, G. (2018). The Determinant Factors Causing Turkey Fall Behind Export Competition. Journal of Strategic Research in Social Science. 8(2): 35-54.

Kaya, M.G. and Öz, E. (2016). Enflasyon, Bütçe Açığı ve Para Arzı Ilişskisinin Türkiye Ekonomisi Açısından Değerlendirilmesi: $1980-2014$ Dönemi. Yönetim ve Ekonomi Dergisi. 23 (3): 639-651.

Kılavuz, E. and Topçu Altay, B. (2012). Export and Economic Growth in The Case of The Manufacturing Industry: Panel Data Analysis of Developing Countries. International Journal of Economics and Financial Issues. 2(2): 201-215.

Kızılkaya, O., Sofuoğlu, E. and Ay, A. (2017). Yüksek Teknolojili Ürün İhracatı Üzerinde Doğrudan Yabancı Sermaye Yatırımları ve Dışa Açıklığın Etkisi: Gelişmekte Olan Ülkelerde Panel Veri Analizi. Doğuş Üniversitesi Dergisi. 18(1): 63-78.

Konak, A. (2018). Yüksek Teknoloji İçeren Ürün İhracatının İhracat Hacmi ve Ekonomik Büyüme Üzerine Etkisi; Seçilmiş OECD Ül keleri ve Türkiye Örneği . Yönetim, Ekonomi, Edebiyat, İslami ve Politik Bilimler Dergisi. 3(2): 56-80.

Lee, J. (2011). Export Specialization and Economic Growth Around The World. Economic Systems. 35(1): 45-63.

Özkan, G. and Yılmaz, H. (2017). Ar-Ge Harcamalarının Yüksek Teknoloji Ürün İhracatı ve Kişi Başı Gelir Üzerindeki Etkileri: 12 AB Ülkesi ve Türkiye İçin Uygulama (1996-2015). Bilgi Ekonomisi ve Yönetimi Dergisi. 12(1): 1-12.

Saray, M.O. and Hark, R. (2015). OECD Ülkelerinin İleri-Teknoloji Ürünlerindeki Rekabet Güçlerinin Değerlendirilmesi. Çankırı Karatekin Üniversitesi Iktisadi ve Idari Bilimler Fakültesi Dergisi. 5(1): 347-372.

Sevüktekin, M. and Nargeleçekenler, M. (2007). Ekonometrik Zaman Serileri Analiz: Eviews Uygulamalı. Ankara, Nobel Yayın Dağıtım.

Tarı, R. (2006). Ekonometri. İstanbul, Avcı Ofset.

Telatar, O.M., Değer, M.K. and Doğanay, M.A. (2016). Teknoloji Yoğunluklu Ürün Ihracatının Ekonomik Büyümeye Etkisi: Türkiye Örneği (1996:Q1-2015:Q3). Atatürk Üniversitesi İktisadi ve Idari Bilimler Dergisi. 30(4): 921-934.

Yıldız, Ü. (2017). BRıCS Ülkeleri ve Türkiye'de Yüksek Teknoloji İhracatı ve Ekonomik Büyüme İlişkisinin Panel Veri Analizi. Dumlupınar Üniversitesi Sosyal Bilimler Üniversitesi Dergisi. 53: 26-34.

Yılmaz, Ö.G. (2005). Türkiye Ekonomisinde Büyüme ve İşsizlik Oranları Arasındaki Nedensellik İlişkisi. Ekonometri ve Istatistik. 2: 63-76. 